\title{
The Influence Of Promotion Strategy Through Online Marketing And Word Of Mouth Marketing On The Purchasing Decision Of Zeneos Brand Tire Products PT Gajah Tunggal Tbk. (Case Study at 8 semester Pamulang University Students, Majoring in Management Program for Academic Year 2018/2019)
}

\author{
Eko Juniharto ${ }^{1}$, Ali Mubarok², Arief Budi Santoso ${ }^{3}$ \\ ${ }^{123}$ Universitas Pamulang, Email:alimubarok1310@gmail.com
}

\begin{abstract}
The purpose of this research is to find out and provide empirical evidence of the influence of promotional strategies through online marketing and word of mouth marketing partially and simultaneously on the decision to purchase Zeneos brand motorcycle tire products from PT Gajah Tunggal Tbk. at Pamulang University in 8 Semester Students, majoring in Management Study Program Faculty of Economics, Academic Year 2018/2019. The sampling method uses simple random sampling technique with the type of research used is associative quantitative. The sample used was 100 respondents namely Pamulang University Students 8 Semester, majoring in Management Study Program Faculty of Economics, Academic Year 2018/2019. While the data collection method uses the questionnaire (questionnaire) method. Data analysis methods are validity test, reliability test, classic assumption test, multiple linear regression, correlation, coefficient of determination, and hypothesis testing (partial and simultaneous).The results of this study indicate that there is a positive and significant effect both partially and simultaneously between promotional strategies through online marketing and word of mouth marketing on purchasing decisions for Zeneos motorcycle tire products from PT Gajah Tunggal Tbk. at Pamulang University Students Semester 8, S1 Management Study Program Faculty of Economics, Academic Year 2018/2019, this is indicated by the results of the test and $f$ test with a significance value below 0.05 .
\end{abstract}

Keywords: Online Marketing; Word of Mouth Marketing; Purchasing Decisions.

\section{A. INTRODUCTION}

In this era of globalization, business competition is getting tougher, the development of an increasingly sophisticated technological era from time to time has created the birth of the digital era so that humans have a dependency on technology one of which is the use of the internet. Intense competition between companies makes business people dare to be different from their competitors. One of the efforts made by the company in dealing with this competition is the development of marketing aspects of its products that utilize the sophistication of internet technology through the concept of Online Marketing that can reach consumers from all directions.

According to Kotler and Keller (2013: 568) said that Online Marketing is a way of marketing that is done through computers (and other electronic goods such as laptops, gadgets) by using a communication tool that aims to reduce marketing costs and increase the effectiveness of marketing efforts. The type of marketing of a product with the internet 
that is currently rife by many companies is through social media marketing. Marketing through social media is called social media marketing.

Social media is an important part of a larger and more complete sales, service, communication and marketing strategy and reflects and adapts to the market and the people who interpret it. Based on the image of the type of internet content that is accessed in Indonesia, Indonesians have more access to social media content than other popular content such as entertainment and news. This shows that there is more interest from the Indonesian population towards social media and makes promising opportunities for companies to be able to market their products through social media channels.

One of the popular social media used in social media marketing is Instagram. Companies that are able to win a competition are companies that are smart in anticipating business developments that occur and can capture every opportunity and opportunity that exists. Zeneos Brand Tires Sales Report 2015 - 2018 shows that product sales tend to be volatile or unstable which occurs from 2015 to 2018. It can also be said that it is possible that products are less well known to consumers or the public at large, lack of consumer interest in buying Zeneos tire products, which is also a lack of consumer confidence in Zeneos tire products, and the promotion of Zeneos tires, and the promotion of Zeneos tires has not been maximized.

Based on motorcycle tire sales data in Indonesia, Zeneos brand motorcycle tires are still inferior to other competitors such as motorcycle tires with Corsa, FDR, Swallow, Dunlop, and Michelin brands, which means that market share and consumers still prioritize purchases on brands that are already seen, heard, and famous in various media or circles of society.

Based on the phenomenon in the Zeneos tire company, the researcher is interested in conducting a study entitled "The Effect of Promotion Strategies Through Online Marketing and Word of Mouth Marketing Against the Purchasing Decision of Zeneos Brand Tires for PT. Gajah Tunggal Tbk. (Case Study at 8 Semester Pamulang University students majoring in Management Study Program, Faculty of Economics, Academic Year 2018/2019).

\section{Formulation of the problem}

The formulation of the problem based on the background above is:

1 Is there an influence of online marketing promotion strategies on the decision to purchase Zeneos brand motorcycle tire products in the 8th semester of Pamulang University students, S1 Management Study Program, Faculty of Economics 2018/2019 Academic Year?

2 Is there an influence of word of mouth marketing on the decision to purchase Zeneos brand motorcycle tire products in the 8th semester of Pamulang University students, S1 Management Study Program, Faculty of Economics 2018/2019 Academic Year?

3 Is there a simultaneous influence of online marketing and word of mouth marketing promotion strategies on purchasing decisions of Zeneos brand motorcycle tire products in Pamulang University students in semester 8, S1 Management Study Program, Faculty of Economics, Academic Year 2018/2019?

\section{Research purposes}

1 To find out and provide empirical evidence on the influence of online marketing promotion strategies on purchasing decisions of Zeneos brand motorcycle tire products in Pamulang University students in semester 8, S1 Management Study Program, Faculty of Economics, Academic Year 2018/2019.

2 To find out and provide empirical evidence on the influence of word of mouth marketing on the decision to purchase Zeneos brand motorcycle tire products at the University of

Jurnal Pemasaran Kompetitif, Vol. 3 No. 3 Juni 2020 
Pamulang semester 8, S1 Management Study Program, Faculty of Economics, Academic Year 2018/2019.

3 To find out and provide empirical evidence on the influence of online marketing promotion strategies and word of mouth marketing on purchasing decisions for Zeneos brand motorcycle tire products at Pamulang University students in semester 8, S1 Management Study Program, Faculty of Economics, Academic Year 2018/2019.

\section{B. LITERATURE REVIEW}

\section{Online Marketing}

According to Kotler and Keller (2013: 568) said that Online Marketing is a way of marketing that is done through computers (and other electronic goods such as laptops, gadgets) by using a communication tool that aims to reduce marketing costs and increase the effectiveness of marketing efforts. The online marketing strategy in this study uses indicators as stated by Taneja and Toombs (2014: 59) in the journal Aditya Wardhana (2015) namely (1) Availability of product information or articles that support and provide product guidance for consumers (2) Availability of supporting images needed such as photographs or product illustrations (3) Availability of video displays capable of visualizing products or supporting presentations (4) Availability of transaction tools and variations in payment media.

\section{Management}

Management according to Hasibuan (2012: 1) argues that "Management is the science and art of regulating the process of utilizing human resources and other resources effectively to achieve a certain goal." According to Terry (2010: 9), the management function consists of four main functions known as POAC, namely: Planning (Organizing Function), Organizing (Organizing Function), Actuating (Implementation Function), and Controlling (Control Function).

\section{Marketing}

A system of business activities designed to plan, determine prices, promote and distribute products that can satisfy the desires of achieving company goals is called the Marketing (Stanton in Tambajong, 2013: 1293).

\section{Promotion}

According to Hermawan (2012: 38) "promotion is one of the priority components of marketing activities that inform consumers that a company is launching a new product that tempts consumers to make purchases."

\section{Social media}

Social media is a website-based feature that can form a network and allow people to interact in a community. E-Commerce According to Turban, David, Lee, and Liang (2012: 38), Electronic commerce (electronic commerce, abbreviated as EC, or e-commerce) covers the process of buying, selling, transferring, or exchanging products, services or information through computer networks, including the internet. Some people view the term commerce (e-commerce) just to explain the transactions that can be carried out between these used, some people realize that the term e-commerce is very narrow. 


\section{Word of Mouth Marketing (WOM)}

According to Kotler \& Keller (2013: 568) that Word of Mouth Marketing (WOM) is an act of consumers providing information to other consumers from one person to others (interpersonal) both brands, products and services. Business partners. If this definition is used, some people realize that the term e-commerce is very narrow. According to Kotler \& $\operatorname{Keller}(2013: 568)$ that Word of Mouth Marketing (WOM) is an act of consumers providing information to other consumers from someone to others (interpersonal) both brands, products and services.

\section{Framework of thinking}

Below is an overview of the framework of thinking in this study:

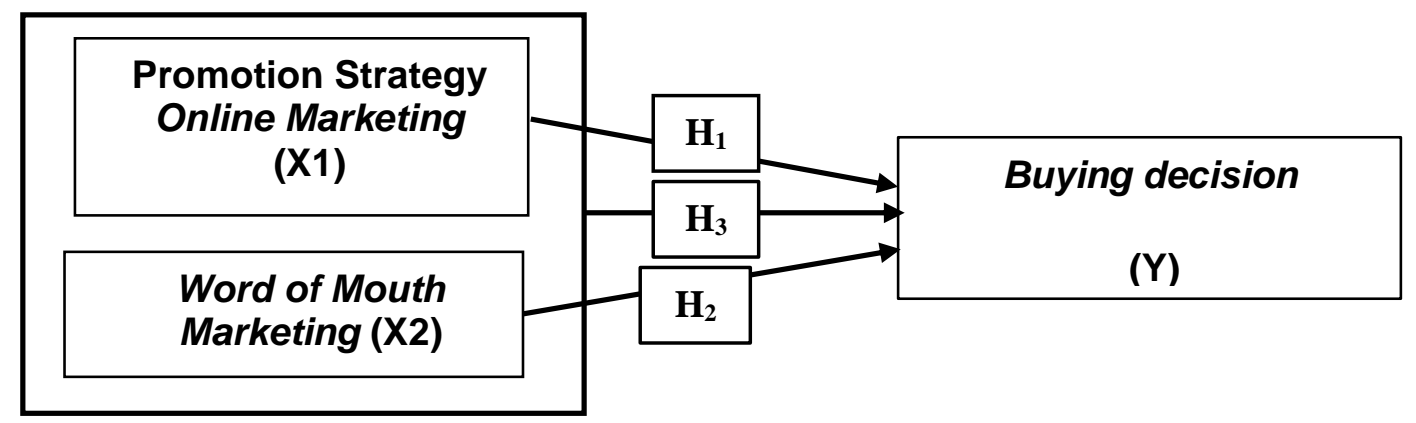

Picture 1

Framework of thinking

$\mathrm{H} 1$ : There is an influence of Online Marketing promotion strategy on purchasing decisions on purchasing decisions for Zeneos brand motorcycle tire products in Pamulang University semester eight students, S1 Management Study Program, Faculty of Economics 2018/2019 Academic Year.

$\mathrm{H} 2$ : There is an influence of Word of Mouth Marketing on purchasing decisions on purchasing decisions for Zeneos brand motorcycle tire products in Pamulang University semester 8 students, S1 Management Study Program, Faculty of Economics 2018/2019 Academic Year.

H3: There is an influence of online marketing promotion strategies and word of mouth marketing on purchasing decisions on purchasing decisions for Zeneos brand motorcycle tires on Pamulang University students in semester eight, S1 Management Study Program, Faculty of Economics 2018/2019 Academic Year.

\section{METHODOLOGY}

This type of research used in this research is an associative method using a quantitative approach. The purpose of this associative method is to find out the influence of online marketing promotion strategies and word of mouth marketing on purchasing decisions of Zeneos brand motorcycle tire products in Pamulang University students in semester 8, S1 Management Study Program, Faculty of Economics 2018/2019 Academic Year. The population used in this study were all Pamulang University Students Semester 8, S1 Management Study Program Faculty of Economics, FY 2018/2019, amounting to 590 students. The sampling technique used is Probability Sampling, which is a sampling technique that provides equal opportunities for each element of the population to be selected as a sample. The sample calculation used is the Slovin formula so that a sample 
of 100 respondents is obtained. The instrument testing uses the validity test, reliability test, test classical assumptions. Analysis of the data used is the Multiple Linear Regression test, Correlation Test, Determination Coefficient and Hypothesis test $t$ and $F$.

\section{RESULT AND DISCUSSION}

\section{Validity test}

Validity test is the ability of a questionnaire so that it can really measure what it wants to measure in this case based on the Validity Test Table Statement Instrument Online marketing promotion strategy (X1), Word of Mouth Marketing (X2) statement instrument and Purchasing Decision Statement Instrument $(\mathrm{Y})$ is above the number 0.166 or (rcount> $r$ table), then all items are declared validly. For this reason, the questionnaire is appropriate for use in research.

\section{Reliability Test}

Table 1

Summary of Reliability Tests

\begin{tabular}{|l|c|c|}
\hline \multicolumn{1}{|c|}{ Variable } & \multicolumn{2}{c|}{ Reliability Statistics } \\
\hline & Cronbach's Alpha & N of Items \\
\hline Online Marketing (X1) & 0.592 & 5 \\
\hline Word of Mouth Marketing (X2) & 0.694 & 6 \\
\hline Purchase Decision (Y) & 0.733 & 4 \\
\hline
\end{tabular}

Source: Data processed by SPSS, 2019

Reliability Test is a test to determine the extent to which the results of a measurement can be trusted. From the results of the calculation of table 1 variable online marketing promotion strategy (X1), Word of Mouth Marketing statement instrument (X2) and Purchase Decision Statement Instrument $(\mathrm{Y})$, it can be said that the questionnaire is reliable because the Cronbach's alpha value $>0.30$.

\section{Classic Assumption Test Results}

\section{a. Normality test}

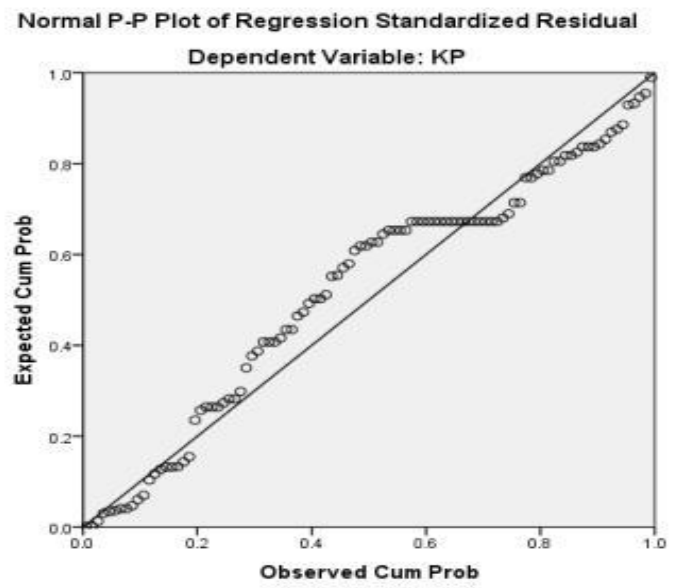

Source: Data processed by SPSS (2019)

Figure 2 PP Plot Normality Test 
Based on the above graph it can be seen that the normal probability plot graph shows normal chart patterns. This can be seen from the points that spread around the normal graph / follow diagonal lines, this shows that the regression model does not violate the assumption of normality.

\section{b. Multicollinearity Test}

Based on Multicollinearity Results with Purchase Decisions as Dependent Variables, the Variance Inflation Factor (VIF) value for Online Marketing (X1) variable is 4,819 and Word of Mouth Marketing (X2) is 4,819, each tolerance variable value is less than 1 and VIF value is less than 10 , with this regression model does not occur multicollinearity.

\section{c. Heteroscedasticity Test}

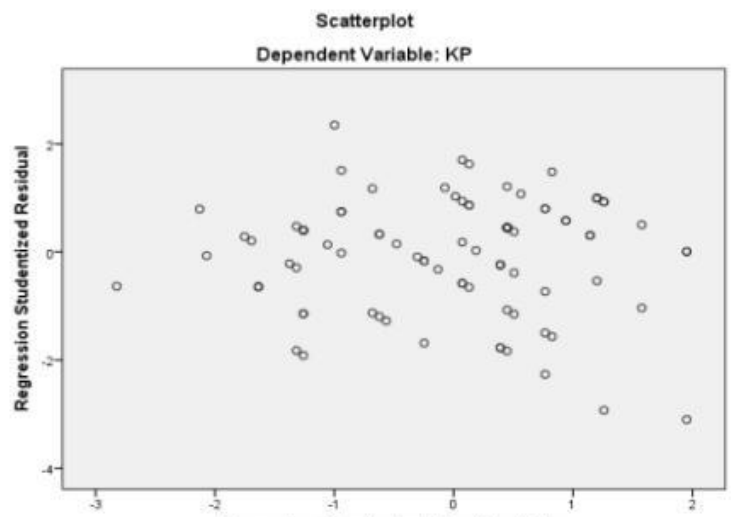

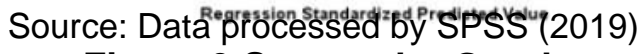

Figure 3 Scatterplot Graph

In Figure 2 the scotter plot can be seen that the points have a clear distribution pattern and the points spread above and below the number 0 and the $Y$ axis, so it can be concluded that there is no interference with heteroscedasticity.

Data analysis method

Multiple Linear Regression Test

Table 2

Multiple Linear Regression Test Results

\begin{tabular}{|c|c|}
\hline Model & Unstandardized Coefficients \\
\hline & B \\
\hline Constant & 1,122 \\
Online marketing promotion strategy & 0.399 \\
Word of mouth Marketing & 0.546 \\
\hline
\end{tabular}

a. Dependent Variable: Buying decision

Source: Data processed by SPSS (2019)

From table 2 we get the multiple regression equation $\mathrm{X} 1=0.399$ and $\mathrm{X} 2=0.546$ the regression equation model is obtained $Y=1.122+0.399 \mathrm{X} 1+0.546 \mathrm{X} 2$, which means:

a.

constant value of 1.122 , means that if the variable Online marketing promotion strategy 
(X1) and Word of Mouth Marketing (X2) statement instrument there is no or constant or zero value, then there has been a Purchase Decision of 1,122 .

b.

Regres sion coefficient Online marketing promotion strategy (X1) equal to 0.399 means if the value Online marketing promotion strategy (X1)an increase of 1 (one) point while Word of Mouth Marketing is assumed to be constant, it will cause an increase in purchasing decisions of 0.399 points.

c.

Regres

sion coefficient Word of mouth Marketing of 0.546 means that if Word of Mouth Marketing an increase of 1 (one) point while online marketing is assumed to be constant, it will cause an increase in purchasing decisions by 0.546 points.

\section{Correlation Test}

\section{Table 3}

Correlation Coefficient Test Results

\begin{tabular}{|c|c|}
\hline Model & $\mathrm{R}$ \\
\hline 1 & 0795 \\
\hline
\end{tabular}

Source: Data processed by SPSS (2019)

Based on table 3, the correlation coefficient test results can be seen that, the correlation coefficient ${ }^{\circledR}$ is 0.795 where Strategy Promotion Online marketing and Word of Mouth Marketing has a strong and simultaneous relationship to purchasing decisions ( $\mathrm{Y}$ ) because 0.795 is between $0.600-0.799$.

Determination Coefficient Test (R2)

\section{Table 4}

Determination Coefficient Test Results (R2)

\begin{tabular}{|c|c|}
\hline Model & $R$ Square \\
\hline 1 & 0.632 \\
\hline
\end{tabular}

Source: Data processed by SPSS (2019)

Determination coefficient ( $\mathrm{R}$ Square) of 0.632 means Online marketing (X1) and Word Of Mouth Marketing (X2) contributed to the purchasing decision $(Y)$ of $63.2 \%$.

\section{Hypothesis test}

Partial Test Results (t test)

Table 5

Partial Test Results (t test)

Coefficient

\begin{tabular}{|c|c|c|}
\hline Model & $\mathrm{t}$ & Sig. \\
\hline $\begin{array}{c}\text { Online Marketing Promotion } \\
\text { Strategy (X1) }\end{array}$ & 10,489 & 0.00 \\
\hline Word Of Mouth Marketing (X2) & 12,904 & 0.00 \\
\hline
\end{tabular}

a. Dependent Variable: Purchase Decision

Source: Data processed by SPSS (2019)

Based on the partial test results table ( $t$ test) as follows:

a. Effect of Online Marketing Promotion Strategy (X1) on Purchasing Decisions (Y). 
There is an influence of online marketing promotion strategy (X1) on the purchase decision $(\mathrm{Y})$ with a significance value of $0,000<0.05$ and the value of $t$ count $>t$ table is $10.489>1.9845$, so the first hypothesis is accepted that there is a positive and significant effect between variables online marketing promotion strategy towards purchasing decisions of zeneos brand tires at Pamulang university students in semester 8 of the S1 Management Faculty study program Academic Year 2018/2019.

b. Effect of Word of Mouth Marketing (X2) on Purchasing Decisions (Y).

There is an influence of Word of Mouth Marketing (X2) on Purchasing Decisions ( $Y$ ) with a significance value of $0.000<0.05$ and obtained $t$ count $>t$ table of $12,904>1.9845$ so that the second hypothesis is accepted meaning there is a positive and significant influence between the Word of Mouth Marketing variables on the decision to purchase zeneos brand tires at Pamulang university students in semester 8 of the S1 management study program Faculty of Economics Academic Year 2018/2019.

\section{Simultaneous Test Results (Test F)}

Table 6

Simultaneous Test Results (Test F) ANOVA

\begin{tabular}{|c|c|c|}
\hline Model & F & Sig. \\
\hline Regressions & 83,163 & 0.00 \\
\hline
\end{tabular}

a. Dependent Variable: Purchase Decision

b. Predictors: (Constant), Online marketing, Word of Mouth Marketing Source: Data processed by SPSS (2019)

Based on table $F$ above, with df (n1) 2 value, df (n2) 97 , and a significance level of $5 \%$ or 0.05 , the $f$ table value is 3.09 . From the results of the $F$ test can be obtained the value of $F$ count $>F$ table that is $83.163>3.09$ and sig value $<0.05$ or $0.000<0.05$ there is a simultaneous influence between Online Marketing promotion strategies (X1) and Word of Mouth Marketing (X2) on the Zeneos Brand Tires Purchase Decision in Pamulang University management students, so Hypothesis three was accepted.

\section{E. CONCLUSION}

\section{Conclusion}

Based on the research results of multiple linear regression test shows that the promotion strategy through Online Marketing (X1) and Word Of Mouth Marketing (X2) both partially and simultaneously influence the decision to purchase zeneos brand tires from PT Gajah Tunggal Tbk. in Pamulang university students in semester 8 of S1 management study program Faculty of Economics Academic Year 2018/2019 with a significance value below 0.05 with Strong correlation. And the Determination Coefficient (R Square) of $63.2 \%$ means Online marketing (X1) and Word Of Mouth Marketing (X2) contributed to the purchasing decision $(Y)$ of $63.2 \%$.

\section{Suggestion}

Companies must further increase marketing back both in terms of increasing online and offline promotions with advertisements and other social networks that are even more interesting. 


\section{EFERENCES}

AMMorissan. (2010). Advertising communication integrated marketing. Jakarta: Kencana Publisher.

Algifari. (2015). Regression Analysis for Business and Economics. 3. Yogyakarta edition: BPFE. Alma, B. (2013). Marketing Management and Marketing Services. Bandung: Alfabeta.

Appley Empat.

A L. d. (2010). Introduction to Management. Jakarta: Salemba

Assauri, S. (2013). Marketing Management. Jakarta: Rajawali Press.

Danang, S. (2013). Accounting Research Methodology. Bandung: PT. Refika Aditama Ikapi Member.

Daryanto (2011). Marketing Management: Course Study. Bandung: One Nusa

E. TurbanD. K. (2012). Electronic Commerce 7 years old Edition. United States: Pearson.

Ghozali, I. (2013). Application of Multivariate Analysis with SPSS Program. Seventh edition. Semarang: Diponegoro University Publisher Agency.

Handoko, D. (2013). Marketing Management, Analysis Consumer behavior. Jakarta: BPFE-Yogyakarta.

Hartono, J. (2012). Portfolio Theory and Investment Analysis, Eighth Edition. Yogyakarta: BPFE.

Hasan. (2011). Research Methods and Statistics. Jakarta: Erlangga.

Hasibuan, SM (2012). Human Resource Management, Sixteenth Printing. Jakarta: PT Bumi Aksara.

Marketing. Jakarta: Erlangga. Kotler, P. d. (2012). Principles of Marketing, Issue 13, Volume 1. Jakarta: Erlangga.

Olson, P. d. (2013). Consumer Behavior and Marketing Strategies. Ninth Edition. Translated by: Diah Tantri Dwiandani. Jakarta: Salemba Empat Publisher

Puntoadi, D. (2011). Increase Sales Through Social Media. Jakarta: Elex Gramedia.

Rangkuti, F. (2010). Spiritual Leadership in Business. Jakarta: PT. Gramedia Main Library

Santoso, S. (2012). Statistics Parametic. Jakarta: PT Gramedia General Library.

Sudaryono. (2016). Marketing Management. Yogyakarta: Andi Publisher.

Sudjana. (2012). Method Statistics. Bandung: Tarsiti.

Terry, G. d. (2010). Basic-Basic Management, Eleventh Printing. Jakarta: PT Bumi Aksara.

Thomafi, F. (2011). Template. Tangerang: Riez Home Publisher.

Tjiptono, F. (2010). Strategic Marketing. Yogyakarta: CV Andi Offset.

\section{Journals}

Edelvisa, A. (2018). The Influence of 2018 Castrol Friends Day Event on Castrol Motor Oil Purchasing Decisions in PT Castrol Indonesia Jabodetabek Region. Journal of Marketing Management Research.

Ermansayah. (2015). Interest Indicators Buy Consumer. Journal of Marketing Concepts (AIDA).

Hermawan, A. (2012). Marketing Communication. Jakarta: Erlangga. Holilah (2016). Effect of Sales Promotion on Purchasing Decisions on Cinere Enchantment

Depok Residence. Journal of Marketing Management. Kotler $\quad$ P., $\quad$ K. $\quad$ (2013). Management 
Krisnamurti, D. (2012). There are several reasons why online shops are increasingly in demand by the public. Retrieved from ini.com:http://inilah.com/some of the reasons that cause online shops increasingly in demand by the public

Melva. (2015, December 1). The Tough Power Behind Word Of Mouth (WOM). Retrieved from kompasiana.com: http://www.kompasiana.com/Strong and Tangguh in Flip Word Of Mouth (WOM)

Purnomo, WD (2017, May 16). What is Social Media Marketing. Retrieved February 11, 2019, from www.semseomanagement.com: http://www.semseomanagement.co m / What is Social Media Marketing

Tambajong, G. (2013). Marketing Mix Influence Against Bicycle Sales Motorcycle Yamaha In PT.Magnificent Commercial Facilities of Kerta Manado. Journals EMBA 1291 Vol.1 No.3 September 2013, Thing. 1291-1301 ISSN 23031174.

Wardhana, A. (2015). Strategy Promotion Strategy Digital Marketing And the implication OnCompetitive Advantages of SMEs in Indonesia. Journal of Business Administration, Chapter III, Page 6. 